\title{
Depotplastre som administrasjonsprinsipp for legemidler
}

\author{
Et transdermalt terapeutisk system eller depotplaster er en legemid- \\ delform som gir kontrollert transport av virkestoff gjennom huden. \\ Depotplaster har et vidt bruksområde og anvendes stadig mer i Norge \\ så vel som internasjonalt. \\ Se også kunnskapsprøve på www.tidsskriftet.no/quiz
}

Depotplastre (eller transdermale terapeutiske systemer) har vært i bruk i nesten 30 år (1). På det norske markedet finnes det ti forskjellige virkestoffer, tilsvarende 19 preparater, registrert som depotplastre. Depotplaster dekker så forskjellige indikasjoner som behandling av sterke smerter, symptomatisk behandling av mild til moderat Alzheimers demens, prevensjonsmiddel for kvinner, hormonsubstitusjonsbehandling og profylakse mot angina pectoris (e-tab 1) (2). Ved depotplastre unngås førstepassasjemetabolisme i lever, og effekten er uavhengig av variasjoner i absorpsjon fra tarmen. Det er økende bruk av denne administrasjonsformen, og det forventes en rekke nye preparater i fremtiden.

\section{Materiale og metode}

Grunnlaget for artikkelen er et ikke-systematisk litteratursøk i Scifinder Scholar med et skjønnsmessig utvalg av artikler basert på forfatternes erfaring innen feltet, samt på Felleskatalogens nettsider.

\section{Hud som applikasjonssted}

Huden består av tre lag: overhuden (epidermis), lærhuden (dermis) og underhuden (hypodermis). I absorpsjonen av legemidler fra plaster er det dermis og epidermis som er relevant. Enkelte av blodårene i dermis ligger kun $0,2 \mathrm{~mm}$ under hudoverflaten, noe som åpner for rask systemisk absorpsjon (3, 4). Overhuden består av fem lag med ulike fysiologiske egenskaper. Det ytterste laget, stratum corneum, fungerer som hovedbarriere mot innvirkning fra miljøet, og avhengig av lokalisasjon er den 0,006-0,8 mm tykk. Viktig for legemiddelopptak er den lagvise oppbygningen med 15-20 lag hornceller som omgis av en intercellulær matriks av ulike lipider og fettsyrer. Oppbygningen likner en murstruktur, hvor steinene tilsvarer cellene og mørtelen lipidblandingen $(4,5)$. Denne strukturen gir to mulige ruter for legemiddeltransport: transcellulær og intercellulær. Den intercellulære er den viktigste (6). Transport av virkestoff gjennom det lipofile stratum corneum skjer passivt via diffusjon, og det er derfor stort sett bare lipofile molekyler som penetrerer intakt stratum corneum.

Det intakte stratum corneum danner hovedbarrieren for transport av legemidler. Den farmakokinetiske profilen til en enkelt dose deles inn i tre faser.

Først skjer det en forsinkelse før virkestoffet blir målbart i blodplasmaet. Det skyldes at stratum corneum først mettes med virkestoffet, samt at det tar en viss tid før virkestoffet diffunderer gjennom stratum corneum. Dernest ser man en likevektsfase hvor plasmakonsentrasjonen av virkestoffet er konstant. Endelig kommer en reduksjon i plasmakonsentrasjon etter at plasteret fjernes. Denne nedgangen viser også en forsinkelse fordi depotet i stratum corneum tømmes.

Når et nytt plaster appliseres på et nytt sted, er nedgangen og stigningen i plasmakonsentrasjonen fra henholdsvis det gamle og det nye plasteret like stor, slik at plasmakonsentrasjonen ideelt sett forblir konstant (7). Det er imidlertid ikke mulig å generalisere farmakokinetikken ettersom den påvirkes av egenskaper ved virkestoffet, ulik plassering på kroppen, metabolisme i huden, $\mathrm{i}$ hvor stor grad huddepotet dannes, samt at de forskjellige plastertypene gir ulik frigjøring.

\section{Prinsippene for depotplaster}

Det første depotplasteret ble godkjent av Food \& Drug Administration (FDA) i 1979 og var et såkalt membran depotplaster (1). I membransystemer ligger virkestoffet løst eller dispergert $\mathrm{i}$ et reservoar med væske eller gel. På yttersiden er reservoaret beskyttet med en folie, mens den andre siden er i kontakt med en membran som kontrollerer frigjøringen av virkestoffet. En limflate hefter plasteret til huden og tillater transport av virkestoffet (fig $1 \mathrm{a}$ ). Det finnes fortsatt to preparater på det norske markedet med denne tradisjonelle formen selv om oppbygningen innebærer visse ulemper, som komplisert konstruksjon og fare for plutselig frigjøring av virkestoffet ved en eventuell skade på reservoaret (dose dumping). Frigjøringen av virkestoffet blir kontrollert av diffusjonshas- tigheten gjennom membranen. Ideelt sett betyr dette en tidsuavhengig lineær frigjøring (0. ordens kinetikk). En annen ulempe med denne konstruksjonen er at den initialt kan gi utilsiktet rask frigjøring fordi virkestoffet diffunderer inn i membranen og limflaten før bruk. Virkestoffet i limflaten blir dermed frigjort før diffusjonen gjennom membranen bestemmer frigjøringshastigheten (4).

I nyere typer depotplastre er virkestoffet enten oppløst eller dispergert $i$ en matriks. Yttersiden av matriksen er dekket med et beskyttelseslag, mens det på innsiden ligger en limflate. Noen depotplastre med matriks har et ekstra putelag for beskyttelse (fig $1 \mathrm{~b}$ ). I andre enda mer forenklede systemer er matriksen både virkestoffbærer og limflate (drug in adhesive) (fig $1 \mathrm{c}$ ). Frigjøring av virkestoff fra matrikssystemer følger ikke en lineær kinetikk, men ettersom frigjøringen er raskere enn hudens opptak, vil huden gi en lineær absorpsjon (4). Mer moderne systemer kombinerer begge prinsipper. I disse systemene brukes både en membran som kontrollerer frigjøring, og en matriks som virkestoffbærer for å unngå uønsket frigjøring av virkestoff ved eventuell skade (fig 1 d) (4).

Administrasjon av legemidler via plaster er ikke påkrevd eller ønskelig for alle indikasjoner. Dertil er det få virkestoffer som egner seg til transdermal bruk, noe som begrenser utvalget. For diffusjon gjennom overhuden bør virkestoffet ideelt ha en lav molekylvekt (<600 g/mol) (4). Virkestoffet må både kunne diffundere gjennom stratum corneum og deretter bli tatt opp gjennom blodårene til den systemiske sirkulasjonen, og det må derfor både ha lipofile og hydrofile egenskaper (1).

Det er spesielt viktig at virkestoffet har en lav totaldose, slik at plasterstørrelsen ikke blir for stor. Generelt egner virkestoffer med en daglig dose under $2 \mathrm{mg}$ seg godt for bruk i plaster med en overflate på mindre enn

\section{Hovedbudskap}

- Depotplastre er godt akseptert av pasienter, noe som øker etterlevelsen (compliance)

- Etter en viss forsinkelse initialt gir depotplastre en jevn transport av virkestoff gjennom huden

- Det er bare få virkestoffer som egner seg til bruk i slike plastre 
Membranplaster

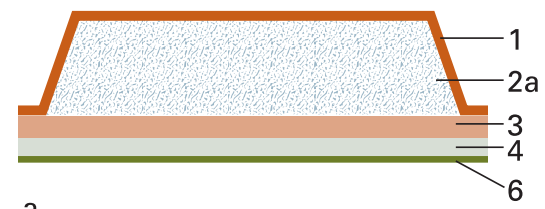

a



b

Matriksplaster med virkestoff

i limflaten

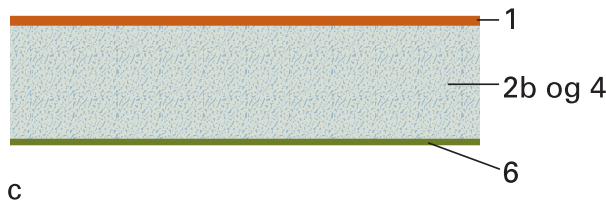

Membrankontrollert matriks

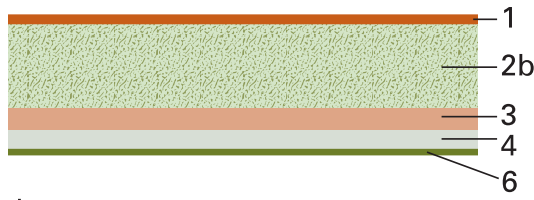

1 Ikke-permeabel ytterside

2a Reservoar

2b Matrikslag

3 Frisettingsregulerende membran

4 Limflate

5 Belegg/beskyttelseslag

6 Beskyttelsesfolie som tas av før bruk

Figur 1 Oppbygning av de mest vanlige depotplastertypene. a) Membrankontrollert plaster, b) Matriksplaster, cl Matriksplaster med virkestoffi limflaten (drug in adhesive), d) Membrankontrollert matriks

$40 \mathrm{~cm}^{2}$, som anses som maksimal størrelse med tanke på hefteegenskaper, kosmetiske faktorer og pasientkomfort $(4,8)$. Virkestoffet skal i tillegg være kjemisk og fysikalsk stabilt, helst ikke metaboliseres i huden samt ha et lavt smeltepunkt. Siden plastrene vanligvis er festet til huden over lang tid, er det viktig at verken virkestoff eller hjelpestoffer har toksiske, allergifremkallende eller irriterende egenskaper.

Det er gjort mange forsøk på å forbedre legemiddelformen ved bruk av passive metoder som gir raskere frigjøringshastighet. Dette innebærer for eksempel bruk av substanser som forbedrer penetrasjonen, prodrugs og supermettede systemer (9). For å $ø$ ke frigjøringen ytterligere benyttes det andre metoder som for eksempel iontoforese, elektroporasjon, ultralyd, mikronåler eller høy temperatur. Preparater basert på disse teknologiene befinner seg imidlertid i tidlig utviklingsfase eller utforskes i prekliniske studier. En oversikt over ulemper og fordeler ved depotplaster er vist i e-ramme 1.

\section{Hudreaksjoner}

Plastre kan forårsake hudirritasjoner, som pruritus, erythema og forbrenning. Disse bivirkningene er ofte koblet til feilbruk, for eksempel bruk på samme hudområde over en lang periode. Slike reaksjoner er vanligvis begrenset til det hudområdet hvor plasteret er brukt og forsvinner oftest kort tid etter seponering.

Hudreaksjoner skyldes virkestoff, metabolitter eller hjelpestoffer, og limflaten kan gi irritasjon ved fjerning av plasteret. Depotplaster med okklusjonsegenskaper øker faren for hudirritasjoner fordi dette kan tilstoppe svettekjertler, og fordi det fuktige, varme miljøet skaper gode betingelser for bakterievekst. Det er viktig å forebygge hudirritasjoner ved å bruke forskjellige hudområder, eventuelt forsøke synonyme preparater, bruke kortere applikasjonsintervaller eller bruke lokale kortikosteroider i forkant.

Det er rapportert allergiske reaksjoner fra bruk av alle depotplastre på markedet. At depotplaster kan fremkalle allergi, skyldes tre viktige faktorer: okklusjon, irritasjon og gjentatt bruk av allergifremkallende substanser på samme hudområde. De fleste pasienter vil tolerere orale legemidler med samme virkestoff etter seponering av plaster (10).

Det er også rapportert om depotplastre som hefter dårlig til huden, både på grunn av feilbruk og dårlige produktegenskaper (11). Hvis plasteret faller av, bør det enten festes på nytt eller et nytt plaster kan festes på. Dette bør i så fall normalt skiftes på samme tidspunkt som det gamle skulle skiftes. Ved prevensjonsplastre kan beskyttelse ikke garanteres hvis plasteret har vært av i mer enn 24 timer, og mekaniske prevensjonsmidler må brukes i tillegg til et nytt plaster. Hvis et depotplaster faller av uten at pasienten merker det, kan dette, i tillegg til å innebære tapt effekt for pasienten, representere en fare for miljøet og andre personer som kan komme i kontakt med virkestoffet.

\section{Konklusjon}

Transdermale terapeutiske systemer er et alternativ for administrering av legemidler. Depotplaster er generelt godt akseptert av pasientene. Per i dag er det kun et fåtall virkestoffer formulert som depotplaster, men det forventes at antallet øker med ny teknologi.

\section{Stefan Hupfeld}

stefan.hupfeld@uit.no

Institutt for farmasi

Det medisinske fakultet

Universitetet i Troms $\emptyset$

9037 Tromsø

Vi takker Lars Småbrekke, Institutt for farmasi, Universitetet i Tromsø og Franz Gruber for nyttige diskusjoner om artikkelens innhold og formål og for språklig hjelp.

Oppgitte interessekonflikter: Ingen

e-tab 1 og e-ramme 1 finnes i artikkelen på www.tidsskriftet.no

\section{Litteratur}

1. Brown M, Martin G, Jones S et al. Dermal and transdermal drug delivery systems: current and future prospects. Drug Deliv 2006: 13: 175-87.

2. Felleskatalogen. www.felleskatalogen.no/ (1.11.2008)

3. Sand O, Haug E, Sjaastad ØV. Fysiologi: en grundbog. København: Munksgaard, 2004

4. Barry BW. Transdermal drug delivery. I: Aulton $M E$, red. Pharmaceutics : the design and manufacture of medicines. 3. utg. Edinburgh: Churchill Livingstone, 2007: 565-89.

5. Moghimi HR, Barry BW, Williams AC. Stratum corneum and barrier performance: a model lamellar structural approach. Drugs Pharmaceut Sci 1999; 97: 515-53.

6. Barry BW. Novel mechanisms and devices to enable successful transdermal drug delivery. Eur J Pharm Sci 2001; 14: 101-14.

7. Berner B, John VA. Pharmacokinetic characterization of transdermal delivery systems. Clin Pharmacokin 1994: 26: 121-34

8. Bartholomäus J. Drug delivery systems for opioids. I: Buschmann H, Christoph T, Friderichs E et al, red. Analgesics: from chemistry and pharmacology to clinical application. Weinheim: Wiley, 2002: 247-63.

9. Williams AC, Barry BW. Penetration enhancers. Adv Drug Deliv Rev 2004; 56: 603-18.

10. Musel AL, Warshaw EM. Cutaneous reactions to transdermal therapeutic systems. Dermatitis 2006: 17: 109-22.

11. Wokovich AM, Prodduturi S, Doub WH et al. Transdermal drug delivery system (TDDS) adhesion as a critical safety, efficacy and quality attribute. Eur J Pharm Biopharm 2006; 64: 1-8.

Manuskriptet ble mottatt 20.2. 2008 og godkjent 8.1. 2009. Medisinsk redaktør Anne Kveim Lie. 